\title{
WSPOMNIENIE
}

\section{E. Pałasz-Rutkowska}

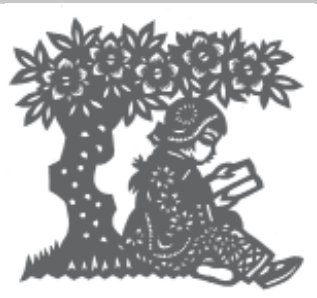

\section{PROFESOR WIESŁAW KOTAŃSKI (1915-2005) wybitny uczony, japonista, wychowawca pokoleń'}

W dniu 8 sierpnia 2005 r. odszedł od nas Profesor Wiesław Kotański, wielki uczony, wybitny japonista, kulturoznawca, językoznawca, religioznawca, thumacz literatury japońskiej, a przede wszystkim niestrudzony badacz źródeł kultury Japonii, w tym najstarszej kroniki, pochodzącej z początków VIII w. Kojiki (Księga dawnych wydarzeń). Był naszym Mistrzem, Wielkim Autorytetem, Ukochanym, choć Surowym Nauczycielem, Przyjacielem, Opiekunem i Wychowawcą, Przewodnikiem na drodze studiów japonistycznych. Był nestorem polskiej japonistyki, twórcą japonistyki powojennej, wspaniałym wychowawcą wielu pokoleń.

Zapytany o przyczyny Swego zainteresowania Japonią w 1999 r., gdy obchodziliśmy 80. rocznicę nawiązania oficjalnych stosunków między Polską a Japonią, a także 80. rocznicę nauczania języka japońskiego na Uniwersytecie Warszawskim, Profesor odpowiedział:

„Fazę pierwszą stanowiły dwa na poły przypadkowe »spotkania« lub »zbiegi okoliczności«. Jedno - to natrafienie (gdy miałem 5-6 lat) na opowieść w czasopiśmie dla dzieci »Moje Pisemko« [...], w którym przedstawiono po polsku treść mitu japońskiego o białym zajączku z Inaby. [...] Z kolei drugi pomyślny zbieg okoliczności, to wielokrotne oglądanie w towarzystwie dziadka ze strony matki zdjęć z wojny japońsko-rosyjskiej [...]. Z pewnością nawet sam pokaz zatapiania krążowników mógł zafascynować dorastającego chłopca [...].

\footnotetext{
${ }^{1}$ Tekst ten został przygotowany na podstawie mojego wystąpienia podczas zebrania plenarnego Komitetu Nauk Orientalistycznych PAN (10 listopada 2005), a jego pierwsza wersja ukaże się w „Przeglądzie Orientalistycznym”.
} 
Faza druga - w szkole powszechnej i średniej nie zetknąłem się z tematyką japońską. [...] Bogaty program nauczania języków obcych w szkole średniej [...] obudził we mnie żywe zainteresowania językami w ogóle i to głównie w perspektywie struktury języka. Ujawniła się też w tej fazie druga tendencja, może najpierw nieco słabsza od lingwistycznych skłonności, ale z czasem podniesiona do rangi indywidualnej predylekcji [...] [związana ze zdobywaniem wiedzy o starożytnych Rzymianach i Grekach, głównie o ich poglądach, filozofii, mitologii, literaturze - E. P. R.].

Faza trzecia. Po ukończeniu w 1936 r. liceum [Gimnazjum Collegium] musiałem jako maturzysta podjąć ważną decyzję, $[. .$.$] jaki obiorę kierunek. Na poloni-$ stykę się immatrykulowałem, ale [...] wydawała mi się mniej atrakcyjna niż języki obce. [...] dowiedziałem się o Szkole Wschodoznawczej, która prowadziła wykłady z zakresu języków afrykańskich i azjatyckich. [...] z listy propozycji bez większego wahania wybrałem naukę japońskiego, co z pewnością podsunął mi drzemiący w podświadomości »zając $\mathrm{z}$ Inaby « lub duch »dziadka podziwiającego Japończyków «². A także, o czym wiem z rozmów z Profesorem, lektura przekładów na język polski opowieści o Japonii Lafcadio Hearna, czyli Koizumiego Yakumo, które także znajdowały się w bibliotece Jego dziadka.

W 1934 r. Profesor został więc studentem polonistyki na Uniwersytecie Warszawskim, ale nie podejmując tych studiów, zaczął, jak Sam stwierdził po wielu latach, „stawiać swe pierwsze kroki, usiłując wkraść się w tajniki mowy i kultury japońskiej”’3 w Sekcji Japońskiej Szkoły Wschodoznawczej przy Instytucie Wschodnim subsydiowanym przez Ministerstwo Spraw Zagranicznych jako ośrodek studiów politycznych nad obszarami Azji i Afryki. Tam po raz pierwszy zetknął się z językiem japońskim, który w trakcie trzyletnich studiów był dla Profesora językiem głównym, obok ubocznych: malajskiego, angielskiego i rosyjskiego. Naukę praktyczną języka prowadził Umeda Ryōchū, który po wojnie stanie się znawcą i propagatorem kultury polskiej w Japonii, a pomagali mu bracia Miszkiewiczowie, Bolesław i Mieczysław. Zajęcia z geografii, historii i literatury Japonii prowadzili profesorowie UW, Witold Jabłoński i Jan Jaworski.

Od tego czasu szczególne zainteresowania Profesora zaczęły koncentrować się wokół Japonii. Ponieważ jednak japonistyka jeszcze nie istniała w strukturach Uniwersytetu, po uzyskaniu dyplomu Szkoły Wschodoznawczej w 1938 r. (po czterech, a nie trzech latach z powodu służby wojskowej), zdecydował się na studia w Katedrze Sinologii, ale o charakterze indywidualnym, stworzonym przez profesorów Jabłońskiego i Jaworskiego. W przyszłości miał poprowadzić na UW specjalizację japonistyczną. Od 1919 r. odbywały się tu zajęcia z języka japońskiego,

${ }^{2}$ W. Kotański, Refleksje na 80-lecie, [w:] Chopin - Polska - Japonia. Katalog wystawy z okazji 80. rocznicy nawiqzania stosunków oficjalnych między Polska a Japoniq oraz Roku Chopinowskiego, Tokio 1999, s. 24.

${ }^{3}$ Ibidem, s. 23. 
nad czym czuwał doc. dr Bogdan Richter, który w 1920 r. utworzył Zakład Kultur Dalekiego Wschodu.

Niestety, wkrótce potem wybuchła wojna. W latach 1940-1944 Profesor Kotański brał udział w tajnym nauczaniu zarówno w domach obu profesorów, jak i u wielu innych wybitnych specjalistów (m.in. T. Kotarbińskiego, H. Hiża, J. Krzyżanowskiego, S. Baleya). Dzięki temu po wojnie, w 1946 r., po zdaniu specjalnych egzaminów uzyskał tytuł magistra. Jego praca magisterska dotyczyła semantyki układów haseł w chińskich i japońskich słownikach hieroglificznych. Po latach Profesor stwierdził, że podczas studiów chodziło mu „o przyswojenie rzetelnej wiedzy o azjatyckim Dalekim Wschodzie i zdobycie kompetencji naukowca, który zgłębia zagadnienia kultury odległych społeczeństw i potrafi je obiektywnie interpretować"4.

W 1946 r. Profesor zaczął karierę zawodową, naukową i dydaktyczną na Uniwersytecie Warszawskim - został asystentem przy Katedrze Sinologii z obowiązkiem prowadzenia zajęć japonistycznych. W 1951 r. otrzymał stopień doktora, co pozwoliło na zatwierdzenie rok później przez rektora specjalizacji japonistycznej i seminarium japonistycznego w ramach sinologii. Uzyskanie stopnia docenta w 1954 r. prowadziło już w prostej linii, ale wyłącznie dzięki staraniom Profesora, do kreowania z japonistyki samodzielnej dyscypliny: w $1956 \mathrm{r}$. powstała sekcja przy Zakładzie Sinologii, a w 1969 r. niezależny zakład w ramach Instytutu Orientalistycznego. Wielokrotnie wyjaśniał światu strukturę, znaczenie i rolę japonistyki polskiej, pisząc na ten temat artykuły w różnych językach, a przede wszystkim w japońskim. Czuwał nad rozwojem sekcji przez trzydzieści z górą lat, wspierany przez rosnące grono swoich wychowanków. Zawsze przejmowały Profesora sprawy środowiska akademickiego, znajdował czas i energię, by aktywnie uczestniczyć w działalności Instytutu Orientalistycznego. Pełnił wiele funkcji na Uniwersytecie, m.in. prodziekana Wydziału Neofilologii (1952-1954), wicedyrektora (1969-1972 i 1972-1974) i dyrektora (1974-1976) Instytutu Orientalistycznego, dziekana Wydziału Neofilologii (1978-1982).

Przede wszystkim jednak Profesor był niestrudzonym badaczem japońskiej kultury, czego najlepszym dowodem są bardzo liczne publikacje ${ }^{5}$, kilkaset pozycji w wielu językach, m.in. dzięki którym w 1975 r. uzyskał tytuł profesora zwyczajnego. Wiedzę na temat japońskiej kultury, religii, języka zdobywał także w Japonii, gdzie był trzynaście razy, a po raz pierwszy wyjechał w $1957 \mathrm{r}$. Szczególnie blisko związany był Uniwersytetem Kokugakuin (Kokugakuin Daigaku), gdzie prowadzone są badania nad źródłami japońskiej kultury, nad rodzimą religią shintō. La-

\footnotetext{
${ }^{4}$ W. Kotański, Wspomnienia z początków japonistyki w Polsce i inne refleksje, „Japonica” 2000, nr 12, s. 35.

${ }^{5}$ Zob. np. Księga dla uczczenia 75 rocznicy urodzin Wiestawa Kotańskiego, „Rocznik Orientalistyczny” 1990, t. XLVI, z. 2, s. 13-21; „Japonica” 1994, nr 2, s. 171-187.
} 
tem roku 1969 r. w Państwowym Instytucie Badań nad Językiem Japońskim (Kokuritsu Kokugo Kenkyūjo) zajmował się metodami nauczania języka japońskiego dla nie-Japończyków.

Zanim jednak Profesor Kotański wyznaczył sobie kierunek poznawczy, kierunek Swych badań, długo poszukiwał. Zaraz po wojnie stanął przed poważnym dylematem: czy kierować zainteresowania na dzieje doktryny buddyzmu, co zalecał wcześniej profesor Jaworski, czy też wybrać inną drogę, ponieważ pomysłodawca zginął w czasie wojny, a zgromadzony przez niego stutomowy zbiór przekładów chińskich i japońskich buddyjskiej Tripitaki spłonął w czasie oblężenia Warszawy w 1939 r. Swe samodzielne dociekania badawcze Profesor rozpoczął od leksykografii. Myślał o opracowaniu słownika japońsko-polskiego, ale wkrótce zrezygnował z tego zamiaru. Następnie podjął badania dziejów znajomości Japonii w Polsce, do czego zachęciła Go bibliografia polskich publikacji o Japonii opracowana przez Kamila Seyfrieda. Powstało wówczas kilka prac, m.in. o wzmiankach na temat Japonii u księdza Piotra Skargi Pawęskiego, a także artykuł Stosunki kulturalne między Polska a Japonią ${ }^{6}$, który stał się inspiracją mych badań nad historią kontaktów polsko-japońskich. Wkrótce Profesor uznał jednak, że jest to tylko margines wiedzy o kulturze Japonii. Postanowił więc zająć się przekładami z języka japońskiego, dzięki czemu miłośnicy literatury mogą do dziś zapoznawać się z cennymi przykładami literatury klasycznej, jak chociażby z antologią najwartościowszych utworów z okresu od IV do XIII w. Dziesięć tysięcy liści (Man'yōshī; Warszawa 1961), czy z pracą badacza szkoły narodowej z XVIII w. Uedy Akinariego Po deszczu przy księżycu (Ugetsu monogatari, Warszawa-Wrocław 1968), a także z utworami nowszymi, np. z Kraina śniegu (Yukiguni; Warszawa 1964) Kawabaty Yasunariego.

Profesor Kotański zgłębiał także teorię przekładów oraz poszerzał wiedzę o języku japońskim, cofając się do jego starszych faz. Wynikiem tego była także Jego praca doktorska Językoznawcza problematyka przy przekładach ze współczesnego języka japońskiego na język polski (1951). W końcu lat 60. XX w. Profesor skupił się na badaniach semiotycznych, a wyniki badań opublikował m.in. w artykule Semiotyczne podstawy interpretacji symbolu religijnego (na materiale japońskim) („Studia Semiotyczne” 1972, nr 3). Zajmował się też japońskimi religiami, głównie rodzimym shintō̄ i stopniowo centrum Jego badań stał się najstarszy, a pochodzący z początku VIII w. zabytek japońskiego piśmiennictwa, cenne dzieło narodowej literatury oraz święta księga shintoizmu Kojiki.

\footnotetext{
${ }^{6}$ W. Kotański, K. Seyfried, Stosunki kulturalne między Polska a Japonia, „Przegląd Orientalistyczny" 1961, nr 2, s. 141-156.

${ }^{7}$ Napisał m.in.: Zarys dziejów religii w Japonii, Warszawa 1963; Religie Japonii, [w:] Zarys dziejów religii, Warszawa 1964, s. 78-114; Zwyczaje, obrzędy i symbole religijne Japonii, [w:] Zwyczaje, obrzędy i symbole religijne, Warszawa 1974, s. 141-266.
} 
Z czasem Profesor postawił tezę, że ,japoński mit o pierwotnym chaosie nie stanowi osobnej całości, lecz tworzy jednolity system wspólnie z długą sekwencją teofanii, których światotwórcza rola polega na zmniejszeniu stopnia entropii w materii świata, a więc na przekształceniu stanu chaotyczności w stan uporządkowania" ". Profesor zdefiniował zbiór zawartych w Kojiki mitów jako idealny plan przygotowania Ziemi na zejście bogów nieba, którzy utworzą dynastię cesarską. Uważał, że kronika ta toruje drogę tym wszystkim, którzy czując się odpowiedzialnymi za losy świata i ludzi, starali się wywrzeć wpływ swą twórczością. Próbował rozwiązać zagadkę - co kryje się pod hermetyczną przesłoną stworzoną przez starożytnych Japończyków, aby w jak najbardziej adekwatnej formie przekazać opowieści o bogach i ich prawnukach, którzy zawitali na Ziemię. Przez lata powstała i ewoluowała szczególna nauka, kojikologia Wiesława Kotańskiego. Profesor uznał, że kluczem do wyjaśnienia zagadki są imiona bóstw i postaci, które, według Niego, mają swe konkretne znaczenie, odzwierciedlające ich rolę w mitologii, są ważne dla całości dzieła i przebiegu narracji, i dlatego powinny być thumaczone. Budziło to - i budzi nadal - kontrowersje, głównie w Japonii, wśród badaczy bardzo ortodoksyjnych, uważających, że jest to naruszanie świętości. Poglądy takich badaczy na temat Kojiki nie zmieniły się zasadniczo od drugiej połowy XVII w., kiedy to „święte księgi” zostały zinterpretowane przez wielkiego badacza szkoły narodowej Motooriego Norinagę.

W pierwszym etapie studiów nad Kojiki Profesor opierał się na intuicji, japonistycznej wiedzy i doświadczeniu badawczym, ale robił to zgodnie z tradycją japońskich badań literaturoznawczych. Prowadził żmudne dekodowanie i interpretację treści ksiąg. Po latach odkrył, że nie można traktować tego tekstu, tak jak tekstu współczesnego - postanowił podejść do tekstu tak, jak to robili jego kompilatorzy.

Drugi etap rozpoczął się wraz z latami 80. Wtedy to Profesor przeszedł od czystej intuicji ku rozpoznaniu przegłosów, zwrócił uwagę na intonację ośmiu samogłosek w starożytnym japońskim, a nie pięciu, które istnieją współcześnie. Pomysł pochodził od profesora Murayamy Shichirō, który zaznajomił Profesora z japońskimi słownikami intonacji i przekonał, że tylko badanie intonacji, jaką przybierają chińskie ideogramy, którymi zapisana jest historia w Księdze dawnych wydarzeń, może dać dobre wyniki. Za pomocą praw morfonemiki i grafemiki języka japońskiego z VIII w. Profesor próbował wykryć utrwaloną w piśmie, w starożytnym tekście, informację o normach, wyobrażeniach i postępowaniach postaci. Taka wiedza okazała się niesłychanie znacząca dla przekładu japońskiej mitologii i wpłynęła na zmianę poglądów Profesora Kotańskiego ${ }^{9}$. Doszło do reinterpretacji, rewizji wcześniejszych interpretacji - Profesor potem wielokrotnie przypominał, że

\footnotetext{
${ }^{8}$ W. Kotański, Refleksje na 80-lecie, s. 25.

${ }^{9}$ Zob. m.in.: W. Kotański, Ukryta warstwa znaczeniowa w japońskiej kronice „Kojiki”, [w:] „Przegląd Orientalistyczny” 1984, nr 1-4, s. 3-12.
} 
jego pierwsze i uznane za wiekopomne thumaczenie Kojiki, czyli księga dawnych wydarzeń (Warszawa 1986), nie jest do końca poprawne, ponieważ nie wykorzystał w nim właśnie akcentów i intonacji. Odsyłał do Swego kolejnego dzieła Dziedzictwa japońskich bogów (Warszawa-Wrocław, 1995).

Ukoronowaniem badań Profesora Kotańskiego nad Kojiki, jak też wielkim zadośćuczynieniem dla Jego pracy, była poważna publikacja ogłoszona w Japonii wiosną 2004 r. przez tokijskie wydawnictwo Kinseisha, Kojiki-no atarashii kaidoku. Kotansuki-no Kojiki kenkyü-to gaikokugoyaku Kojiki (Nowe [metody] dekodowania Kojiki - studia Kotańskiego nad Ksiega dawnych wydarzeń na tle innych pozajapońskich przekładów. Edytorem i redaktorem jest profesor Matsui Yoshikazu, językoznawca, antropolog kultury i religioznawca z Międzynarodowego Uniwersytetu w Osace (Ōsaka Kokusai Daigaku), który przez wiele lat współpracował z Profesorem Kotańskim i dzięki któremu część trudnych, a niezmiernie ważnych prac Kotańskiego została przetłumaczona na język japoński.

Za wspaniałe osiągnięcia, za wielkie zasługi w tworzeniu i rozwijaniu polskiej japonistyki, za promocję kultury japońskiej w Polsce Profesor był wielokrotnie nagradzany i odznaczany. W 1973 r. otrzymał Krzyż Kawalerski Polonia Restituta, w 1977 Order Świętego Skarbu za osiągnięcia w badaniach kultury Japonii, a w 1986 r. Order Wschodzącego Słońca przyznany przez cesarza Japonii w uznaniu wybitnych zasług $\mathrm{w}$ dziedzinie promowania wiedzy o Japonii w Polsce i współpracy naukowej między Polską a Japonią. W 1990 r. Fundacja Japońska (Kokusai Kōryū Kikin; The Japan Foundation) przyznała Mu nagrodę indywidualną, a w 1998 r. władze okręgu metropolitalnego Osaki XVII Nagrodę Yamagaty Banto, za wybitne zasługi w propagowaniu kultury japońskiej za granicą, a szczególnie za całokształt badań nad Kojiki.

Profesor Wiesław Kotański był z pewnością uosobieniem historii powojennej polskiej japonistyki. Niestety, jak już kilka lat temu Sam zauważył, zainteresowanie jego kierunkiem badań w Polsce wyraźnie osłabło. Ostatnią, wytrwałą uczennicą, była dr Agnieszka Żuławska-Umeda, która pod kierunkiem profesora napisała swą rozprawę doktorską. Był nim także wspomniany prof. Matsui. Ale Profesor Kotański niezależnie od specjalizacji, był Niezastąpionym i Wspaniałym Nauczycielem wielu pokoleń japonistów. Jego uczniami są niemal wszyscy polscy pracownicy japonistyki na Uniwersytecie Warszawskim, znaczna część kadry w nowszych ośrodkach japonistycznych na Uniwersytecie Jagiellońskim i Uniwersytecie im. Adama Mickiewicza w Poznaniu, część z uczniów rozjechała się po świecie.

Był niestrudzonym w przekazywaniu Swej ogromnej wiedzy o kulturze Japonii i bardzo surowym Nauczycielem. Miałam niebywały zaszczyt i przyjemność niepozbawioną czasami strachu i obaw, szczególnie na początku mych japonistycznych studiów - być Jego uczennicą. Pod Jego kierunkiem pisałam pracę magisterską, uczyłam się pierwszych japońskich znaków, tłumaczyłam pierwsze teksty. Zaskakiwał zawsze ogromną wiedzą, sumiennością, przygotowaniem do każdej 
rozmowy. Swą wiedzą dzielił się z nami niemal do końca Swych dni - jeszcze na początku 2005 r. prowadził dla nas, pracowników japonistyki warszawskiej, seminaria poświęcone swym ostatnim badaniom i związanym z nimi przemyśleniom oraz wątpliwościom, co do trafności wysnuwanych teorii. Jeszcze w czerwcu tego roku, nie szczędząc Swego czasu, wyjaśniał mi, sugerował, jak zapisywać długie imiona japońskich bóstw.

Był moim - naszym - Mistrzem, Nauczycielem i Wychowawcą. Uczył nie tylko, jak zgłębiać tajniki japońskiej kultury, ale też jak żyć, jak rozwiązywać problemy dnia codziennego. Uczył skromności, obiektywizmu, wytrwałości, rzetelności. Pozostanie na zawsze w mojej pamięci i wiem, że nikt nigdy nie zastąpi mojego - naszego - Profesora.

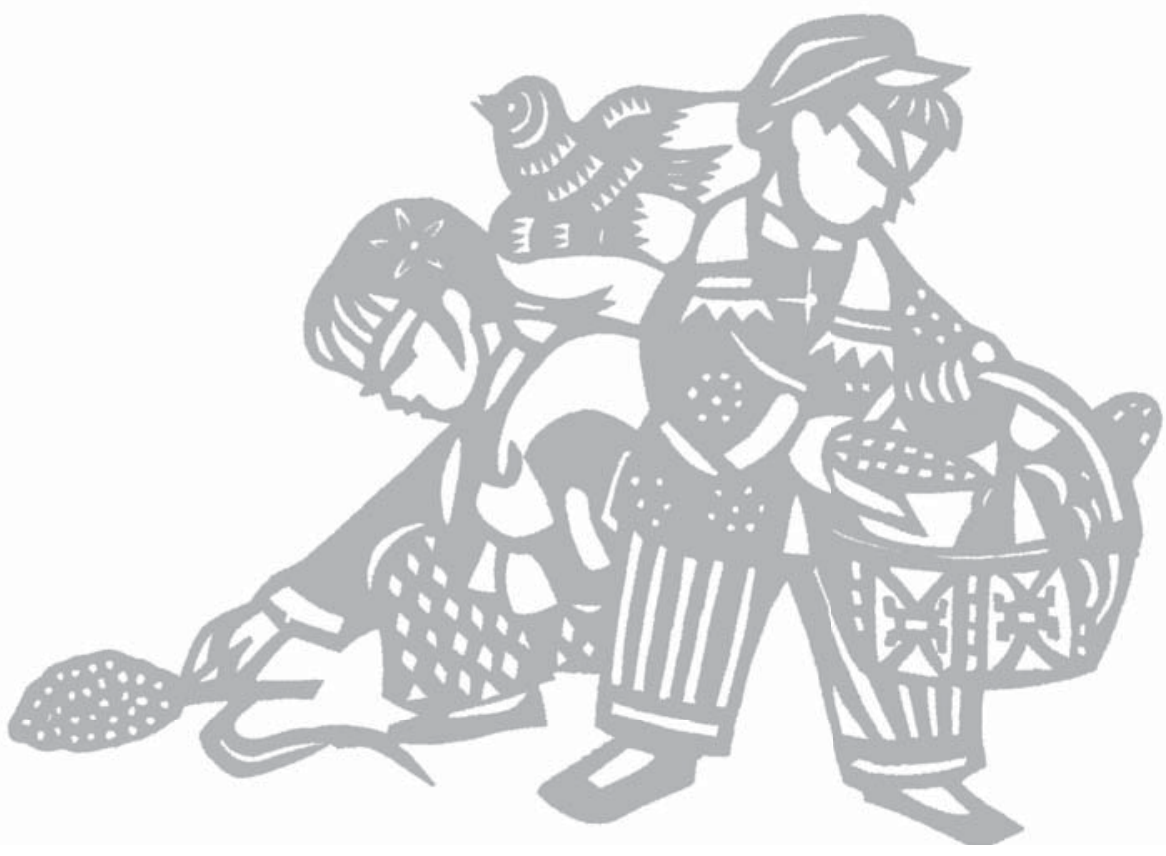

